\title{
Changes in the serum transaminases in patients with syphilis
}

\author{
B. S. TIO, C. H. BEEK, E. C. VAN REEDE, AND M. G. VAN DEN BERG \\ From the Department of Venereology, Medical Faculty, Rotterdam Academisch Ziekenhuis, Dijkzigt, \\ Rotterdam, The Netherlands
}

Syphilis of the liver was frequently mentioned with detailed descriptions and discussion in the earlier literature. There were uncommon cases of jaundice associated with early syphilis and 'hepato-recurrence'; reputedly latent hepatic disease as shown by abnormal biochemical test results; solitary or multiple gummata ; and diffuse interstitial cirrhosis. From the 1940s onwards proof gradually emerged that most cases of liver disease in patients with syphilis were due not to the syphilis but to the effects of therapy, or to syringe-transmitted viral hepatitis, or to coincidental disease - especially cirrhosis; the last could arise from various causes but particularly alcoholism.

At the present time syphilis is recognized as a rare cause of liver disease, and the report by Spirov, Prodanov, Bonev, and Stefanov (1966) is therefore surprising in that it indicated that serum transaminase activity was increased in a significant proportion of 55 patients, most with early syphilis. The glutamic oxaloacetic transaminase (SGOT) was raised in 49 per cent. of cases before treatment and the glutamic pyruvic transaminase (SGPT) in 18 per cent. After treatment with penicillin, and also after bismuth, the proportions of cases with increased transaminase activity rose, 90.9 per cent. showing a raised SGOT and 43.6 per cent. a raised SGPT. Values for both enzymes soon fell to normal after the completion of treatment in the majority of cases. Spirov and his colleagues attributed the raised pre-treatment levels to syphilitic infection of the liver parenchyma and the raised levels during treatment to destruction of spirochaetes causing further parenchymal inflammation; in some cases it was considered that a second rise in levels was an effect on the parenchyma of bismuth therapy.

The authors acknowledged that their interpretations were speculative and advised further studies. A search of the dermatological literature has revealed that raised SGPT and SGOT levels were found incidentally in cases of collagen disease (Vickers, 1961; Wüst, Langrehr, and Horn, 1958), and of

Received for publication April 27, 1970 psoriasis vulgaris, atopic dermatitis, and lichen planus

(Tickner, Mier, and McNabe, 1961).

In the present investigation the SGOT and SGPT

values were ascertained in a larger group of luetic patients who were examined more frequently before, during, and after treatment.

\section{Material}

The eighty cases in our series comprised fourteen cases of seronegative primary syphilis, fourteen cases of primary.syphilis in which serum tests changed from non-reactive to reactive, sixteen cases of seropositive primary syphilis, seventeen cases of secondary syphilis, and nineteen cases of late syphilis. In all cases of primary syphilis, Treponema pallidum was found by darkfield examination either of the lesion or of inguinal lymphatic gland aspirate. Standard $\triangle$ serum tests for syphilis and TPI tests were performed in all cases.

\section{Method}

The following examinations were carried out. SGPT and SGOT by the method of Reitman and Frankel (1957) - O normal values below 40 units $/ \mathrm{ml}$. Alkaline phosphatase: Bessey-Lowry method-normal values 18 to 45 international units. Zinc sulphate turbidity - normal values $2 \dot{\delta}$ to 12 units.

The patients were examined before, during, and after treatment with penicillin; specimens were taken nearly every week and on all occasions samples were taken in the $D$ morning before breakfast. For comparison purposes there were twenty persons from the normal population.

Results Table I (overleaf) shows the numbers among all $\mathrm{C}_{\mathrm{C}}^{\mathrm{N}}$ eighty cases examined with either normal results to all tests or at least one abnormal result in one test - the numbers in each group are classified in relation to the stage of syphilis and the stage of treatment.

Table II (overleaf) presents the mean values of results for each test and the standard errors of the means, related to the stage of syphilis and its treatment in the cases of 58 patients whose test results yielded normal values throughout the study. Statistical analysis shows that there was no significant difference in the frequency of abnormal results to the SGOT, SGPT, 
TABLE I Results in eighty patients treated with 30 m.u. penicillin

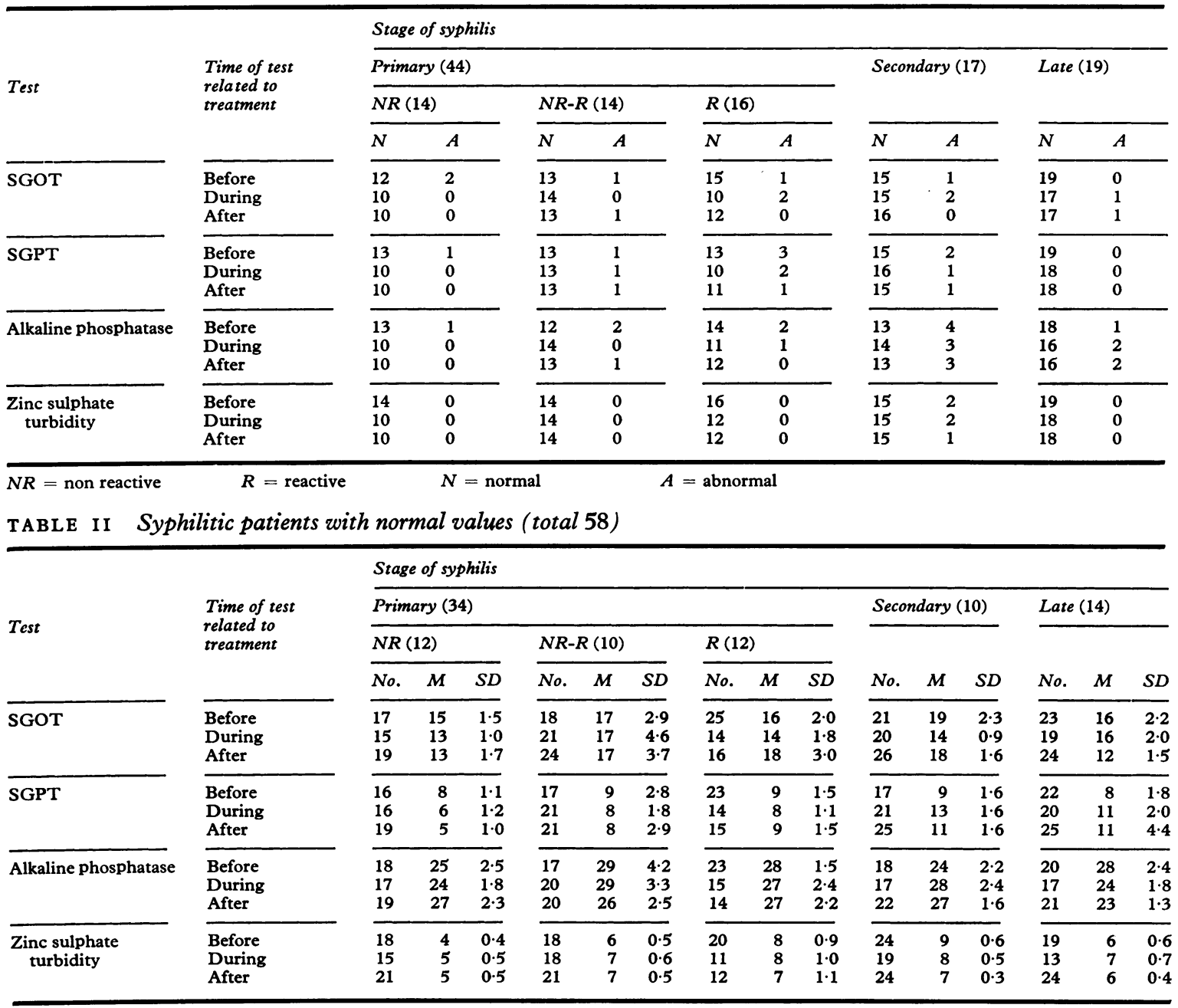

and alkaline phosphatase between syphilitic patients and the normal population (20 control cases). Furthermore, Table II shows that neither the stage of syphilis nor treatment with penicillin influenced the results of the tests.

Table III presents mean results of sequential tests of the SGOT, SGPT, and alkaline phosphatase in each of the 22 cases in which one or more abnormal value was returned, the cases being grouped according to the stage of infection. In the first sixteen cases listed, the abnormal values were either of minor degree or were inconstant: physical examinations had revealed no other evidence of disease and it was thought most likely that the abnormal values were due to minor laboratory errors. There were six cases in which raised values to all three tests were fairly constant. Further investigation in these cases revealed that five patients were chronic alcoholics. In the sixth case no cause could be determined; this patient defaulted before further examinations could be completed.

\section{Summary}

The values of the SGOT, SGPT, alkaline phosphatase and zinc turbidity were determined sequentially in eighty cases of syphilis of various stages before, during, and after treatment. Mean values for all tests did not differ significantly between syphilitics and the normal population. Neither the stage of syphilis nor penicillin treatment appeared to have any 
TABLE II I Results in 22 syphilitic patients with abnormal SGOT test results

\begin{tabular}{|c|c|c|c|c|c|c|c|c|c|c|}
\hline \multirow{3}{*}{ Case no. } & & & \multicolumn{8}{|c|}{ Test } \\
\hline & \multirow{2}{*}{\multicolumn{2}{|c|}{ Stage of syphilis }} & \multicolumn{2}{|c|}{$S G O T$} & \multicolumn{2}{|c|}{$S G P T$} & \multicolumn{2}{|c|}{$\begin{array}{l}\text { Alkaline } \\
\text { phosphatase }\end{array}$} & \multicolumn{2}{|c|}{ Physical examination } \\
\hline & & & $M$ & $S D$ & $M$ & $S D$ & $M$ & $S D$ & No. & Result \\
\hline 1 & Primary & NR & 29 & 5 & 25 & 9 & 23 & 1 & 7 & $\mathrm{~N}$ \\
\hline $\begin{array}{l}2 \\
3 \\
4 \\
5\end{array}$ & & R-NR & $\begin{array}{l}37 \\
15 \\
22 \\
12\end{array}$ & $\begin{array}{r}11 \\
3 \\
6 \\
2\end{array}$ & $\begin{array}{r}24 \\
18 \\
12 \\
6\end{array}$ & $\begin{array}{l}9 \\
5 \\
6 \\
1\end{array}$ & $\begin{array}{l}26 \\
25 \\
24 \\
30\end{array}$ & $\begin{array}{l}1 \\
3 \\
0 \cdot 4 \\
19\end{array}$ & $\begin{array}{r}11 \\
8 \\
7 \\
15\end{array}$ & \\
\hline $\begin{array}{l}6 \\
7\end{array}$ & & $\mathbf{R}$ & $\begin{array}{l}35 \\
12\end{array}$ & $\begin{array}{l}7 \\
3\end{array}$ & $\begin{array}{l}27 \\
12\end{array}$ & $\begin{array}{l}9 \\
2\end{array}$ & $\begin{array}{l}18 \\
41\end{array}$ & $\begin{array}{l}1 \\
5\end{array}$ & $\begin{array}{r}10 \\
6\end{array}$ & \\
\hline $\begin{array}{r}8 \\
9 \\
10 \\
11 \\
12\end{array}$ & Secondar & & $\begin{array}{l}16 \\
18 \\
14 \\
17 \\
20\end{array}$ & $\begin{array}{r}3 \\
3 \\
15 \\
4 \\
6\end{array}$ & $\begin{array}{r}9 \\
19 \\
5 \\
14 \\
14\end{array}$ & $\begin{array}{l}3 \\
5 \\
1 \\
5 \\
4\end{array}$ & $\begin{array}{l}38 \\
33 \\
37 \\
29 \\
24\end{array}$ & $\begin{array}{l}4 \\
3 \\
4 \\
3 \\
6\end{array}$ & $\begin{array}{r}10 \\
13 \\
7 \\
5 \\
10\end{array}$ & \\
\hline $\begin{array}{l}13 \\
14 \\
15 \\
16\end{array}$ & Late & & $\begin{array}{l}25 \\
14 \\
28 \\
15\end{array}$ & $\begin{array}{r}4 \\
2 \\
10 \\
3\end{array}$ & $\begin{array}{r}10 \\
7 \\
5 \\
10\end{array}$ & $\begin{array}{l}2 \\
3 \\
2 \\
1\end{array}$ & $\begin{array}{l}26 \\
38 \\
28 \\
34\end{array}$ & $\begin{array}{l}6 \\
6 \\
0 \cdot 2 \\
4\end{array}$ & $\begin{array}{r}9 \\
9 \\
4 \\
10\end{array}$ & \\
\hline 17 & Primary & NR & 28 & 16 & 39 & 18 & 16 & 1 & 3 & Chronic \\
\hline $\begin{array}{l}18 \\
19\end{array}$ & & $\mathbf{R}$ & $\begin{array}{l}41 \\
42 \\
\end{array}$ & $\begin{array}{r}10 \\
9\end{array}$ & $\begin{array}{l}40 \\
45\end{array}$ & $\begin{array}{l}15 \\
10\end{array}$ & $\begin{array}{l}26 \\
33\end{array}$ & $\begin{array}{l}2 \\
1\end{array}$ & $\begin{array}{r}6 \\
10\end{array}$ & $\begin{array}{l}\text { Cause not } \\
\text { known in } 1\end{array}$ \\
\hline $\begin{array}{l}20 \\
21\end{array}$ & Secondar & & $\begin{array}{l}47 \\
22\end{array}$ & $\begin{array}{l}2 \\
6\end{array}$ & $\begin{array}{l}44 \\
18\end{array}$ & $\begin{array}{r}26 \\
3\end{array}$ & $\begin{array}{l}88 \\
43\end{array}$ & $\begin{array}{r}29 \\
3\end{array}$ & $\begin{array}{l}3 \\
7\end{array}$ & \\
\hline 22 & Late & & 22 & 10 & 3 & 0.3 & 24 & 3 & 3 & \\
\hline
\end{tabular}

influence. There were six patients in whom test values were consistently raised; five of these were chronic alcoholics.

\section{References}

Reitman, S., and Frankel, S. (1957) Amer. F. clin. Path., 28, 56

Spirov, G., Prodanov, K., Bonev, A., and Stefanov, S. (1966) Brit. F. vener. Dis., 42, 129

Tickner, A., Mier, P. D., and MCCABE, M. P. (1961) Brit. F. Derm., 73, 180

VICKERS, C. F. H. (1961) Ibid., 73, 185

Wüst, H., LANGReHR, D., and HoRn, H. D. (1958) Derm. Wschr., 137, 288
Modifications des transaminases sériques chez les malades atteints de syphilis

\section{SOMMAIRE}

Les valeurs des SGOT, SGPT, de la phosphatase alcaline et de la turbidité du zinc furent consécutivement déterminées dans 80 cas de syphilis à des stades différents, avant, pendant et après traitement. Les valeurs moyennes de toutes les épreuves ne se sont pas montrées significa- $O$ tivement différentes chez les syphilitiques par rapport à la population normale. Le stade de la syphilis ni le traite- $\frac{T}{O}$ ment par la pénicilline ne semblèrent avoir d'influence. Chez 6 malades, chex lesquels les réponses aux épreuves $\mathbb{N}$ furent nettement élevées, 5 étaient des alcooliques chroniques. 